\title{
CHARACTERISTICS OF LOCAL GOVERNANCE AFTER 1912 IN ALBANIA
}

Aurora Ndreu'

European University of Tirana, Tirana, Albania

\section{ABSTRACT}

After declaring its independence in 1912, the Albanian state was recognized as such by the great powers only in 1913, during the Peace Conference in London, where besides the important fact of the de jure recognition of Albania as a state in the international arena, it was territorially disintegrated, where more than half of its territories remain outside of the state borders. In the Organic Statute of Albania, Albania was formed as a constitutional principality and hereditary sovereign under the guarantee of six major international states. If the aforementioned Statute, Chapter VI defines the organization of local administration in Albania. We can see for the first time a juridical status of local government in Albania to the most important document of the time. Based on Article 95 of the Statute, Albania was divided into seven sanjaks (units), these were divided in Kaza, and these latter in Nahije. Remaining from the Ottoman conquest of how organized and label, Sanjaks were those of Shkodra, Elbasan, Dibra, Durres, Berat, Korca and Gjirokastra. Regarding the analysis of the organization of local government, as we shall see below, this model is a remnant of the Turkish invaders organization and does not bring any innovation regarding the organization in this period. Such a form of organization had itself the Turkish Empire, which brought in Albania together with the process of invasion for centuries.

\section{UDC \& KEYWORDS}

UDC: 342 '35 ALBANIAN STATE LOCAL GOVERNANCE CHARACTERISTICS UNITS

\section{INTRODUCTION}

As was mentioned before, based on Article 95 of the Statute, Albania was divided into seven sanjaks (units), these were divided in Kaza, and these latter in Nahije. Remaining from the Ottoman conquest of how organized and label, Sanjaks were those of Shkodra, Elbasan, Dibra, Durres, Berat, Korca and Gjirokastra. Sanjak as local unit of that time, constituted the highest organizing locally, and as administrator of this unit served mytesarifi who was the liaison between local and central government. (Faniko, 2014) If we make a comparison with local units today, we can compare with the Prefect as it is considered today, which is the link between local and central government, is the representative of the central government to the local level. In this regard mytesarifi responded to the central government, the Minister of Interior and other ministers depending on the matters covered by each ministry. As the local government senior person, the gendarmerie and police of the province were depended from him. Economically he controlled together with the chief of the finance the accounts throughout Sanjak, so once a year he performed his control in all Kazas, that were part of the Sanjak. He had responsibilities even in relation to the placement of exceptional measures of public safety, but on the other hand these measures can be taken only in cases of urgent and in any case by informing the central 'n.aurora@yahoo.com government. Having a separation of powers, mytesarifi it had no impact and can not interfere with judicial powers exercised by the courts (Organic Law, 1921).

These separation of powers were recognized a time early in the development of the state. In contrast to the organization of today where the Prefect institution is an individual and with him there is no council, which serves legislation, in the organization of 1914, mytesarifi was assisted in the exercise of his functions by the Council of Sanjak (Faniko 2014: 109). This Council exercised the functions of the today administration and this can be seen from the composition of its members ex officio, meaning as a result of the function that they perform as Secretary General, Head Accountant, Director of Education, director of world affairs, the agriculture and trade representatives etc. The functions this council performed may be compare with those that the local legislative body perform today according to the legislation. Such as drafting the budget of the local unit, setting fees, the management of educational institutions, functions relating to urban development, transport and traffic services, agriculture, livestock, etc. This organization was as regarding of the Turkish invasion, so it has no juridical importance for the Albanian State organization. This was done in order to be simple the process of functioning of the state and the fact that people were already familiar with such an organization. One other organization would take time to prepare, be implemented and Albanian state in those moments was too fragile for such reforms. The Kaza unit was governed and administered as by the Statute by a person named Kajmekam. This was in charge to maintain order and security as well as Kaza's finances. This Kaza's administrator decided on issues such as issuing passports, legalization of signatures of officials of Kaza, namely technical issues pertaining to territorial smaller circle. We see an organization close to the needs of individuals and geographical designation closer to the people. As mytesarifi, kajmekam also was assisted in his work by a council with legislative role. This council was called the Council of Kaza and consisted of members appointed on the basis of the function or position they have (as secretary general, accountant, director of tax on land) and 4 members elected by an absolute majority of voters present by municipal councils meeting in the capital of Kaza that were called from kajmekam. The council decided mainly with regard to issues pertaining to the adoption of different tariffs within the territory of the kaza's as establishing fees, at markets or fairs, issuing authorizations etc. So Kaza as local unit can be compared with the organization of the municipal entity, and Nahija (nahiye) organization was defined as a group of villages and can be compare with the municipalities according to the organization before the administrative reform of 2014. The head of nahiye was called mudir.

According to the Organic Law of 26 November 1921, the municipality was defined as local government body, which had its council and mayor (Organic Law, 1921). Elections were made every three years. While the Civil Code of 1928 


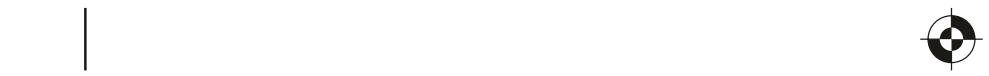

stipulated the creation of municipalities (Article 13). The latter consisted of villages and had a board of directors where village seniors itook part in its composition. On 17 January 1925 the Constitutional Assembly declared Albania a Parliamentary Republic. The Fundamental Statute of the Republic of Albania does not provide in its composition special rules in connection with the administrative division of local government or its organization. On the other hand a special law, the "Law of Civil Administration of the Republic of Albania", approved in 1927 makes a detailed definition not only of administrative division but also for the organization and functioning of local government in that time (Law of Civil Administration, 1927).

The organization and functioning of local government during the Zog presidency (1925-1928)

In 1927 for the first time was adopted a law on the civil administration in the Republic of Albania, which in the first half determined the administrative division of that period (Law of Civil Administration, 1927).

Under this law Albania was divided into prefectures, subprefectures, municipalities, provinces and villages. Seen in this law, Zog with coming to power, required an administrative organization reform according to the Western model through this organization. For any new organization or reorganization it was required the adoption of a new law. Unless the villages formed a new neighborhood, or wanted to change his existing border, these were made with the approval of the Ministry of Internal Affairs and the decision was based on the administrators subprefectures or prefectures advice. Despite ongoing efforts to reshape the conception of local government, again we see remnants of the Ottoman organization, at least in mentality, because almost all the functions were depending on the central government look. We can see below some of the features of the administrative functions of the time. Starting from the prefect who was in charge of the higher administrative organization at the local level, and going through to the subprefecture, province and a village. On top of these organizations stood respectively the prefect, deputy prefect, krahinari (the province person in charge), while at the top of the village stood the "Seniors of the village".

The prefect was the highest official in this institution and he was appointed by a decree of the President of the Republic on the proposal of the Ministry of Internal Affairs and following the decision taken by the Council of Ministers. Prefect represented the highest official within the territory of the prefecture, and was representative of all government ministries. We see a similarity between the position of prefect in this case with that under current law regarding representation of central government to local government.

Any law that needed to be adopted and implemented, it should be given to prefectures which were responsible for the disclosure of the offices within its territory in connection with the law in question. Among the duties of the prefect were those of providing tranquility within the territory of the prefecture where exercising the function and respect the independence of judicial bodies and the execution of decisions taken. To realize the function of maintaining public order, the prefect expolited the use his rights regarding the police and gandarmerie within the jurisdiction of the prefecture, who were obliged to implement any order by means of a letter that was given from him. Also pursuant to the above function, the prefect had the right to exploit all the military power that was under the jurisdiction of the territory where he exercised. Twice a year the prefect performed inspections in offices and centers within the jurisdiction of the prefecture and on the basis of these inspections prepare reports for the Ministry of Internal Affairs. Regarding to the powers mentioned above, it appears that the Prefect had a great power that included many areas within the territory of the prefecture. This high functionally role who was given the prefect as representative of the central government at the local level shows once again for a strengthening of power in the hands of central government which leaves nothing for the desired application of the principle of local autonomy in this case.

Deputy prefect was the most senior officer of subprefecture enforcement. As such, he was obliged to preserve and protect the rights of the people and on the powers given to ensure law enforcement. Also we can mention control of the decisions taken by the council of provinces, on regard of their legal basis.

On the other hand regarding the functions of deputy prefect we can find something which the law did not provide for the prefect. Deputy prefect was supposed to observe the prison, to ensure implementation of rule prisons and if necessary to make appropriate improvements. It should ensure the implementation of the orders of the prefect and control the municipalities.

\section{Local Government during the period of the Kingdom of Zog (1928-1937)}

During this period we see for the first time the creation of a local government tradition. In 1934 for the first time we see an authentic bill concerning the organization and functioning of municipalities. It should be noted that during the reign of King Zog, cooperation with Italian state was at its peaks. This is important for the fact that this law, the first of its kind in Albania, with pretty reformist character, was prosperous and democratic. For the first time we found in the elements of self-government within the opportunities created, where besides a proper organization of local governance, are founded also the elements of an emerging fiscal decentralization. Law dated 30 April 1934 was published in the Official Gazette number 26 on 20 May 1934. If we consider the organization of local government in this period and why he uses precisely this kind of organization, the simple reason is political and economic closeness that Albanian Kingdom under Zog's reign had with Italian state at that time. As we analyzed the various documents at the Central State Archive, we see that King Zog had progressive vision and its aim was to align the country with the best western models.

Through this the municipalities began receiving a sleek form of true western cities. The composition of this law can draw that was quite popular and its content can be compare with laws or those post-communist transition period in Albania.

Administrative division at this time was in prefectures, sub-prefectures, municipalities and villages. The municipality was designated as legal person charged with arranging local needs of its residents (Law on Civil Code, 1928).

We see for the first time the element of legal capacity and legal person with rights and obligations, indicating such a modernize law giving this way a greater independence of local government bodies. Municipal boundaries were set by a sketch which was approved by decision of the Joint Administrative Councils. As it seems, this has more the form of a city regulatory plan or municipalities nowadays. This sketch, after receiving final by municipal councils, should be presented to the Ministry of Internal Affairs from which had to be received the approval and then be approved in the last analysis by the Council of Ministers. 


\section{The City Hall and its responsibilities}

Looking carefully the municipal functions under this law, we did not find any significant changes in relation to the functions that municipalities cover today. So among the tasks that each municipality had, was to provide cleaning and adjustment of the places that are open to public inspection of food or beverages and everything used for public health under the relevant laws and regulations. The city hall had the duty to take care of cleaning, hygiene and public premises where citizens fed or spend their time, and to control everything that was sold or was used in these local life within the requirements of the law.

An important feature was the granting of permits for all constructions, repairs and additions thereto. Any construction done outside the issued permit of the municipality or without the permission of the municipality would collapse, as stipulated by Article 8, paragraph 12 of the law, stating that (Law on Municipalities, 1934).

"... Constructions started outside to the laws or without the consent of the City Hall, will be declined, and against the offender will be desplaid special provisions of this law."

There is another function that we see, that is the regulation and improvement of streets and neighborhoods of the city according to the urban planning, scheduling of classes, names and numbers of roads (the process of addressing the community as seen nowadays), paving the lighting of these roads. On this ground we see the functions of the local unit, but practically it is different how they develop over time and leaves much to be desired. So, between the existence of modern law for the up given period in Albania and its implementation in practice there was a great gap. This is mainly due to the underdevelopment of the society at that time.

Seen in analogy with the functions after 90 s that the local government had, we can find much in common. The mode used during the Zog Kingdom already had enough western character and reformer (Law on Municipalities, 1934). Legislation organizing the local unit was borrowed from Italian legislation, part of civil law and supported features of this type of law.

\section{Organization of the Municipality under the law of 1934}

We also defined previously that the municipality was an institution with legal personality, which was aimed at meeting the needs of the people within the territory in which exercise its jurisdiction.

By organizational means the municipality had some help in the exercise of its functions. And it had its Assembly, the Council, the Mayor and the administration. These organisms are underlined in the law we mentioned previously.

\section{The Assembly of the Municipality}

This assembly consisted of members, whose number depends on the number of population of the municipality.

By analogy that likens the election of members of municipal councils by legislation today, their number depends on the population of the municipality. The definition contained in Article 11 of this Law, in relation to the number of members based on the number of the population as well as additions to the member for any municipality with a population over 30,000 , where per 3000 capita grows a member, is the same concept with the determination made by the current law on the number of council members. Election of members of the assembly was done by the people directly, which took place every four years and the assembly madate begin 15 days after the election. By analogy elections of members of municipal councils under the current legislation, are conducted every four years, and the election is made directly by the people. Once again the determination of the number and manner of election of members through free, democratic and direct elections, sets for the democratic and reformer character of this law. Voters for these elections should have some texture on the basis of the law as such. So they should have been a national Albanian, and be a resident for a period of at least 6 months within the country, have attained the age of 20 years (this age having legal capacity and operating results is greater than the law of our days which defines the age of 18 years old) at the time of voting, the right to enjoy full civil and political rights. Basically such criteria are more regular and better ensure popular representation, but what does not come from this law is that more than half of the population at that time did not know how to read and write. Not to mention that only religious people or those educated abroad had full knowledge of reading and writing. Against this analysis it remains difficult to determine to what extent there was a good representation of the full popular choice, because the people who vote do not know how to read the names of the candidates. The question arises, who voted in their name or how the voting process was developed in such a condition? It's somewhat strange regarding the enjoyment of civil rights of the human being, the last point of Article 13 of the law, which states that (Law on Municipalities, 1934):

"... Voters should not be beggars, soldiers in active service or gendarmerie ..."

According to this point it appears that the law did not allow the people who beg in the streets to vote, it seems to contradict all advancing legislation of the Zog time, the legislation mainly borrowed from the West best practices, that was the Italian one. Not having the right to vote for this category looks like a violation of the rights and freedoms of the individual. While those who could be voted, i.e. municipal assembly members should enjoy the above qualities but also some other qualities, such as not be convicted of an offense against good customs, should not be entrepreneurs who works for the mayor, or friend or guarantor thereof, should not be state officials or companies dealerships in the municipality, should not be members of the Council of state Administration, should not have received any assistance from the budget of the municipality, not be on trial with the municipality, not have in their administration of any movable or immovable property, not to be municipal debtors, not to be religious officials, to know how to speak and write the official language. As we see, there were many limitations regarding the election of persons in the functions of a member of the Assembly of the municipality, this is because the legislator at the time tried to avoid any conflict of interest or relations of the business world with the political governance, thinking of a correct governance and the best interest of the people rather than personal interest of its members. Unfortunately, such a provision does not exist today in the current legislation regarding the persons elected as members of municipal councils, which are representative of the local unit and in which people operate. At its best, today's legislation, as we examined, provides only some limitations but not to a large extent as it was foreseen at the time of Zog. This perhaps made that majority of the members of municipal councils, especially in remote or underdeveloped areas, are persons who at the time of Zog would not be allowed by law to be elected as assembly members. On the other hand this law prohibited explicitly any link it may be between employees of the municipality or council members, which means that it is forbidden to be in the same assembly father and son or uncle and nephew, 
grandfather and great-grandson, mother-in-law with the bridegroom etc, if so it will be another voting of two people in this category, then whoever has the most votes is elected and the other does not become part of the assembly, if they have the same number of votes it will then randomly selected. By analogy with the last local elections in Albania, there are many cases of election as council members, persons with family ties, such as family members who were elected as members. This shows once again, in my view, the level of modernization of the law and its democratic character, compared with the laws of our days.

\section{CONCLUSION}

Local governance after the Albanian independence proclamation was of Turkish characteristics, since Albania was occupied for more than 500 years from Turkey. Regarding this there is anything new until the very important law of 1934, know also as the Zog Law. This law that was approved under the Kingdom of King Zog, it was one of the most important and modern, since it was modeled by the Italian legislation. During that time, Albania and Italy had a very good state relationship. The municipality law of King Zog was on of the best practices regarding its modeling, but it was very difficult to be implemented in practice since the Albanian society was very poor, underdeveloped and not prepared for such a modernization.

\section{REFERENCES}

Faniko, I. (2014). Comparative Constitutional Law Story, Jozef Publications, Tirana.

Law of Civil Administration of the Republic of Albania (1927). Central State Archives.

Law of Civil Code of 1928 (1928). Central State Archives.

Law on Municipalities (1934). Official gazette of May 10, 1934, Central State Archives.

Organic Law of 26 November 1921 (1921). Central State Archives. 